\title{
Self-Immolation in Women: Addressing an Urgent Human Crisis
}

\author{
Mohsen Rezaeian ${ }^{1,}$ \\ ${ }^{1}$ Department of Epidemiology and Biostatistics, Occupational Environmental Research Center, Rafsanjan Medical School, Rafsanjan University of Medical Sciences, \\ Rafsanjan, IR Iran \\ "Corresponding author: Mohsen Rezaeian, Department of Epidemiology and Biostatistics, Occupational Environmental Research Center, Rafsanjan Medical School, Rafsanjan \\ University of Medical Sciences, Rafsanjan, IR Iran. Tel: +98-3434331315, Fax: +98-3431315003, E-mail: moeygmr2@yahoo.co.uk
}

Received 2015 June 23; Revised 2015 October 26; Accepted 2016 March 07.

Keywords: Crisis, Self-Immulation, Women

\section{Dear Editor,}

Self-immolation, or suicide attempted by burning, is one of the most devastating methods of suicide, with up to a seventy percent fatality rate (1). Evidence suggests that young married females who are deprived and illiterate are most prone to committing self-immolation, especially in the Middle Eastern countries (2), India (3), and Sri Lanka (4).

The results of a study revealed that self-immolation is the cause for up to seventy percent of suicides in some regions of Iran. The study's results further highlighted that more than seventy percent of those people who selfimmolated were females with a mean age of twenty-nine (5). Unfortunately, due to ongoing conflicts, less is known about self-immolation in Iraq, where the situation seems to be much worse. Therefore, the present article's emphasis is on self-immolation among Iraqi women as an urgent human crisis.

Burn mortality in the Sulaimani-Kurdistan region of Iraq has been determined to be high (6), especially among self-immolating women (7). Existing evidence also confirms that self-immolation among females has become a serious growing crisis in the Kurdistan region of Iraq, although, due to an inadequate monitoring and surveillance system, the data on self-immolation are considered to be an underestimation, with underreporting in this region (8).

Nevertheless, very recently it has been determined that in the Kurdish region of northern Iraq, five women commit suicide by self-immolation every day (9). These women primarily kill themselves by self-burning in order to flee or protest common incidences of gender-based violence, such as domestic abuse, in their Kurdish communities (10).

Apart from being "female," other independent risk factors for self-immolation in this region are reported as "young age," "poor education," "spring season"and"small family size" (11). What makes the current picture gloomier is that some of these self-immolations are likely to be what is called "murder-immolation" or "homicidal- immolation" (i.e., family members murdering a woman when they believe she has brought disgrace to her family) (12). It has been estimated that from 1997 to 2007, up to 12,500 murder-immolations occurred in the region (10).

It is also worth emphasizing that in other parts of Iraq and after the US-led invasion in 2003 the number of suicides has largely increased especially among young females using self-immolation. Unfortunately, the barbarity and brutality of the so-called Islamic State (IS) group has added to the problem in areas under its control. It is because that IS sells or slaves captured girls and women, especially from religious minorities. As a result, more females have chosen to commit suicide in Iraqi areas under ISIS control, but the extent of this is very difficult to determine at the moment (13).

Under such circumstances, it is absolutely necessary that local and national suicide prevention programs be developed through social campaigns (14) to stop this human crisis in different parts of Iraq. It is obvious that the main prerequisite for implementing such prevention programs is providing stability throughout Iraq by ending the armed conflicts and social unrest.

Moreover, the main themes for local and national suicide prevention programs must, at the very least, take into account "providing social support for females and other high-risk groups," "providing mental health services especially for females and other high risk groups," "women empowerment and changing their inferior role in a patriarchal community," "eradication of illiteracy," "tackling poverty," "providing opportunity for financial improvements," "reducing unemployment," and even, to a lesser degree of importance, "placing barriers to easy access to the means of suicide" $(15,16)$.

\section{References}

1. Rezaeian M. Epidemiology of self-immolation. Burns. 2013;39(1):1846. [PubMed: 23413444]. 
2. Rezaeian M. Suicide among young Middle Eastern Muslim females. Crisis. 2010;31(1):36-42. doi: 10.1027/0227-5910/a000005. [PubMed: 20197256].

3. Rezaeian M. Death by burning in Indian women. Burns. 2014;40(8):1816-7. doi: 10.1016/j.burns.2014.07.016. [PubMed: 25406885].

4. Fernando RF, Hewagama M, Priyangika WD, Range S, Karunaratne S. A study on suicide by self immolation. Ceylon Med J. 2011;56(4):182-3. doi: 10.4038/cmj.v56i4.3906. [PubMed: 22298219].

5. Ahmadi A, Mohammadi R, Stavrinos D, Almasi A, Schwebel DC Self-immolation in Iran. J Burn Care Res. 2008;29(3):451-60. doi: 10.1097/BCR.ob013e31817112f1. [PubMed: 18388564].

6. Qader AR. Burn mortality in Iraq. Burns. 2012;38(5):772-5. doi: 10.1016/j.burns.2011.12.016. [PubMed: 22326976].

7. Othman N, Kendrick D. Burns in Sulaymaniyah province, Iraq: epidemiology and risk factors for death in patients admitted to hospital. J Burn Care Res. 2011;32(4):e126-34. doi: 10.1097/BCR.0b013e3182223ef5. [PubMed: 21593682].

8. Hanna VN, Ahmad A. Corrected and republished: Suicide in the Kurdistan Region of Iraq, state of the art. Nord J Psychiatry. 2013;67(2):1404. doi: 10.3109/08039488.2012.761401. [PubMed: 23330638].

9. Al Jazeera . Burning for justice 2015. [updated May 2015]. Available from: http://www.stream.aljazeera.com/story/2013070401130022879 .
10. BORGEN Magazine . Self-Immolation: Common Death Cause for Iraqi Kurdish Women 2015. [updated May 2015]. Available from: http://www.borgenmagazine.com/self-immolation-commoncause-of-death-for-iraqi-kurdish-women.

11. Othman N. Suicide by self-burning in Iraqi Kurdistan: description and risk factors. Arch Suicide Res. 2011;15(3):238-49. doi: 10.1080/13811118.2011.589717. [PubMed: 21827313].

12. Rezaeian M. The use of "murder-immolation" or "homicidalimmolation" instead of "forced self-immolation". Burns. 2014;40(8):1817-8. doi: 10.1016/j.burns.2014.08.023. [PubMed: 25300757].

13. Global Research. Young Iraqis see Suicide as an Escape [updated May 2015]. Available from: http://www.globalresearch.ca/young-iraqissee-suicide-as-an-escape/5423058.

14. Rezaeian M. Social campaigns are needed to stop any forms of self-immolation. Burns. 2014;40(2):356-7. doi 10.1016/j.burns.2013.09.009. [PubMed: 24268644].

15. Rezaeian M. Age and sex suicide rates in the Eastern Mediterranean Region based on global burden of disease estimates for 2000. East Mediterr Health J. 2007;13(4):953-60. [PubMed: 17955778].

16. Rezaeian M. Suicide/homicide ratios in countries of the Eastern Mediterranean Region. East Mediterr Health J. 2008;14(6):1459-65. [PubMed: 19161122] 